\title{
Social Background and the Spread of Letter from an Unknown Woman in China
}

\author{
Ruihui Han* \\ Humanities School, Jinan University, Zhuhai, Guangdong Province, China \\ *Corresponding Author: Ruihui Han, Humanities School, Jinan University, Zhuhai, Guangdong \\ Province, China

\begin{abstract}
This paper investigates the relationship between the social background of China and the spread of the novella Letter from an Unknown Woman during the period from 1919 until the 21 st century. Although Letter from an Unknown Woman was translated into Chinese in 1933, interpretations of the theme of this novella differed across different periods because of the corresponding social background factors. Among the factors, the policies and attitudes of the government played a vital role in and exerted a direct influence on the interpretation and spread of this novella. However, in addition to the government policies, other factors, such as economy, culture, literary trends, and technology, influenced government policies in different periods. The novella is just like a mirror, reflecting the complicated social change over the past one hundred years.
\end{abstract}

Keywords: Letter from an Unknown Woman; Stefan Zweig; Translation; Spread; China

\section{INTRODUCTION}

Stefan Zweig's novella Letter from an Unknown Woman (Original German title: Brief einer Unbekannten) became well known and popular in China after 2005, when the excellent film director Jinglei $\mathrm{Xu}$ adapted the novella into a film and achieved great success. This novella related the sentimental story about the unrequited love of a woman for a writer. In the beginning of the novella, the writer receives a letter written in a woman's handwriting, without the sender's name and address on it. She tells the writer that she loves him ever since the time she was a girl. She describes the details that they have met many times but he did not recognize her each time, however, they have many interactions across their lives. She gives birth to their son without the knowing of the writer. After their son dies of disease, the woman writes to writer in this letter about all the previous experience between them. Zweig is renowned for his skilled description of the subtle and violent inner conflicts of women. The film director Jinglei Xu was able to capture the essence of this story, and this film shaped Chinese audiences' impression of the film. However, we should note the social background, such as economic situation, political policy, and literary trend, also contributed to the success of the film. Without the suitable social background, such success of this film is unthinkable. Just like the success of this film, the spread of novella Letter from an Unknown Woman was also conditioned by the social background.

This paper discusses the relationship between social background and the spread of novella Letter from an Unknown Woman from 1919 until $21^{\text {st }}$ century. Four periods are discussed. In the next section, the paper addresses the novella in the period from 1919 until 1949. The following section discusses reader response for this novella in the period between 1978 and 1990s, which is the period of era of reform and opening up in China. The next section examines the spread of this novella in the period after 2000. In above mentioned periods, the political, economic, cultural, ideological, and technological factors all contributed to reader response and the spread of Letter from an Unknown Woman in China. Readers of different social backgrounds responded differently to this novella. To some extent, the reader response and the spread of this novella reflects the social changes in China over the past hundred years.

The first period of the spread of this novella is between 1919 and 1949, which was the period of new democratic revolution in China. In this period, translations had specific goals and strong political inclinations, so the translators in that period felt a strong sense of social responsibility and had a sense 
of mission (Di, Aiying. 2007). The translators actively provided Western thought and culture for the new democratic revolution, because the intellectuals who were influenced by Western thinking realised that feudal culture and ideology hindered China's awakening. The rule of the feudal warlords, the invasion of Japan and the social turbulence dominated that period. This complicated situation in China stimulated the intellectuals to learn from the Western world for the advanced technology and thoughts.

Stefan Zweig's works first appeared in 1924 during the new democratic revolution. The first writer to introduced Zweig's work to China was Mao Dun. Mao Dun mentioned Zweig's anti-war plays Jeremiah (Original German title: Jeremias) in his European War and Literature (Mao, Dun. 1924). In this article, Mao Dun said, 'When the others describe war crime... Zweig predicts that the resistance spirit will win ultimately and encourages the readers. (Mao, Dun, 1924). In 1928, Scholar Rengen Yang published his translated book Luoman Luolan (Romain Rolland, Original German title: Romain Rolland. Der Mann und das Werk) written by Zweig. In the preface, Rengen Yang remarked that 'this book reflects the value of both Romain Rolland and Zweig.' (Yang, Rengen.1928).

Before 1949 , the most frequently translated work of Zweig in China was his Letter from an Unknown Woman. The first translation was done by Yiping Zhang and was published in 1933. The Chinese name of this novella is yige furen de qingshu and is the first of Zweig's works to appear in book form in China (Wei, Maoping. 2004). In 1934, the translated novella, titled in Chinese as yige mosheng nvzi de laixin, was serialised in World Literature. In 1935, the novella was listed in the World Literary Classics by the Commercial Press in Shanghai(Wei, Maoping. 2004).

The novella brought a fresh perspective into Chinese literature. Traditionally, China's narrative art tends to have a happy ending(Xu, Fei. 1989), even in tragic stories where a happy ending would be improbable and unrealistic. Letter from an Unknown Woman is a novella with a tragic ending. The woman helplessly loved her charming neighbor until her death. She loved him so passionately that she said: 'I believe that were you to summon me from my death-bed, I should find strength to rise in answer to your call.' (Zweig 1932, P96). These words moved thousands of readers in China. Unlike the literary modes in China tradition, Letter from an Unknown Woman ends with the woman's death. This had a profound impact on Chinese readers who had adapted to the happy ending story. The miserable fate of the woman in the novella moved readers. As a result, many intellectuals advocated for the inclusion of tragic tales. For example, Hu Shi argued that China literature could learn much from Western tragedies. 'What Chinese literature lacks most,' claimed Hu Shi, 'is the notion of tragedy. No matter the novel, or the drama, Chinese stories always have a happy ending. Fundamentally, that sort of literature features only simple thought and cannot inspire introspection,' $(\mathrm{Hu}$, Shi.1918). The tragedy literature from the Western world was also popular among readers. For example, when Guo Moruo talked about the novels he read during that time, he said, 'the novels translated by Lin Shu were popular in that time. I was fascinated with those novels. The first novel of such kind I read was Joan Haste by Haggard. That novel inspired my deep compassion and many tears,' (Guo, Moruo. 1997). Realising the function of the tragedy novel, many Chinese writers also wrote tragedy novels. One such writer, Lu Xun wrote My Old Home and The New Year Sacrifice, which were both tragedy novels. And thus began the popularity of the tragedy among authors, readers, and even critics.

As a tragedy novella, Letter from an Unknown Woman describes the passionate, delicate and sentimental love of the protagonist. The readers of this novella do not regard this novella as pornographic. Maoping Wei remarked that this novella was not like the romantic and erotic novels written by frivolous writers. On the contrary, this novella had deep thought that moved readers (Wei, Maoping. 2004). Golgi, the former Soviet Union writer who greatly influenced Chinese readers, praised the novella: "I cannot remember a novel as pure, chaste, and lyric as Letter from an Unknown Woman"' (Zweig, 2009). Golgi's comment promoted the spread of this novella in China, as he was a celebrity at that time.

From 1949 until 1978, the political requirement, which demanded that the literature should meet the political need, was paramount in translations. Especially from the 1960s, foreign literature translation was often regarded as backward and reactionary. Even former excellent translations of Western literary classics were regarded inferior. In this period, there were fewer than forty published foreign literature translations, and most of them were works from the former Soviet Union, Japan, and other 
friendly countries (Ma, Shikui. 2003). According to the government policy at the time, the translation of foreign literature must have a political mission (Zhang, Guojun. 2008). Only works from friendly countries were allowed to be translated into Chinese. Works from some unfriendly countries could only be translated and circulated as negative examples and references among high-level cadres and researchers. All foreign translations in this period were related to the political struggle and the need of political diplomacy (Zhang, Guojun. 2008). Furthermore, translated foreign works were required to have prefaces or notes by the editors or translators, pointing out the political meanings of the works or guiding the readers to interpret the works politically. In such a political atmosphere, Zweig's novels could not be translated into Chinese again, because it was deemed to promote 'decadent content, unwholesome thoughts, and lacked pedagogical meaning and was considered reactionary' (Zhang, Yushu. 1987). Common readers could not touch Letter from an Unknown Woman, and the evaluation criterion for this novella was political. This situation changed at the end of the Great Cultural Revolution.

After the Great Cultural Revolution, foreign literature translation prospered again. Reform and opening-up policy created an environment where common readers could explore foreign literature. The repression of the previous period promoted an eagerness to translate foreign literature. From 1978 until 2000, the translation and publish of foreign literature can be divided into three stages: the first stage is from 1978 until the middle of the 1980s, the second stage is from the middle of the 1980s until the end of the 1980s, and third stage is from the end of the 1980s until 2000 (Wang, Fuhe. 1996). The first two stages witnessed the translation of foreign literary classics which were banned in the previous period as well as many new modernist foreign literary works (Wang, Fuhe. 1996).

In the first stage, literature played an important role in politics, society, and culture. The typical literature at that time was 'pure' literature, a sort of literature different from both political literature and the subsequent literature catering to the market. Accordingly, in this stage, the translation of foreign literature was mainly about the classics of Western literature, which had been translated previously, such as the works of Shakespeare, Hugo, and Tolstoy.

In the second stage, literature became a commodity. The market economy was advocated by government and became popular in China, so the reading and writing of literature became activities of consuming and producing. As a result, the translation of foreign literature expanded as communication with Western countries broadened and China opened up and embraced reform. More Western works, especially modern literature, were translated into Chinese during this period.

During these two stages, more of Zweig's works were translated into Chinese. In 1981, his translated novel Beware of Pity (Original German title: Ungeduld des Herzens) was published in four publishing houses in mainland China (Zhang, Yan. 2015). Letter from an Unknown Woman also garnered attention during this period. However, compared with other works by Zweig, Letter from an Unknown Woman was translated and published more frequently. In 1979, Zhongshan Magazine published the translated Letter from an Unknown Woman by Shouren Wang. In the same year, People's Literature Publishing House published this novella translated by Yushu Zhang. In the next year, Jiangshu Peoples Publishing House published the translated edition of this novella. From 1979 until 1990, this novella already had five translated editions.

The publishing of this novella not only reflected the literature condition at that time, but also aligned with the literary writing and reading tide. After the Great Cultural Revolution, the 'Hurts Generations' literature (a literature writing exposing the history trauma in the Great Cultural Revolution), misty poetry (the poetry describing the inner world and having misty themes) and other literary writing trends appeared. These literary trends emphasised emotion and sentiment. Zweig's Letter from an Unknown Woman was full of turbulent and delicate passion, so this novella became one focus in foreign literature.

However, this novella was read and regarded changed between the end of 1980s and 2000. One obvious social background change in this stage was the promotion of the market economy in China. Literary works became commercial activities. In the pursuit of profit, publishing houses published thousands of foreign literary works. Likewise, the reading of literary works became the fast-food culture. The phenomenon was not only the result of the rapid publishing of literary works, but also the result of the change of reading tastes. As China evolved economically, so did reading tastes. Among common readers, the economic goal was foremost. Compared with the previous readers, readers in 
this period did not have enough time to think about the emotion or affection represented in literary works. Lighter literature catering to the reading taste of common readers became popular. The publishers found that literary works about sex, money, or other similar themes excited readers and thus sold more; for example, the works of Wei Hui were popular in that time (Lye Yonglin. 2015). Because publishers focused more on publishing these lighter works, this affected the publishing of Letter from an Unknown Woman

During this stage, in order to promote sales, many publishers described and advertised this novel as a pornographic work. Although the novella in itself was a passionate tragedy novella, the publishers emphasised the sexual desires in the book. In China, desire is a word that people associate with sex desire because of the popularity of Buddhism in history. Sex and desire were two common words publishers used to describe the themes of this novella. Publishers added a skewed introduction of Letter from an Unknown Woman to conjure up images of sex and desire. Doing this, publishers effectively promoted the novella, which resulted in earned more profit.

In 1999 , the profit of publishing houses in China increased to $24.75 \%$, which was significant compared to the average profit of other Chinese enterprises at the time, 5\% (Zhu Shenglong. 2001). Breaking previous taboos, the Chinese publishing houses marketed books using erotic descriptions, and this proved to be the magic weapon. Although China's government issued a series of edicts and adopted different measures to curb pornography and illegal publications, erotic books still prospered. Since the founding of the People's Republic of China, the main selling organisation was the Xinhua bookstore in China. However, as the market economy grew in the 1980s, other selling channels appeared, such as the collective-owned bookstore, individual bookstores, private bookstores, and even bookstalls. Such selling channels benefited the sale of books, especially those that broke taboos. Accordingly, many such books came into the market. A new literary writing trend, 'private part writing' came into being at this time. In this type of writing, 'lots of vulgar language, obscene language, combining with desire, sexual impulse, libido, and hormones, pushing the erotic discourse to a new high,' (Chen Zhongyi, 2009; P158).

Not surprisingly, serious and aesthetically elegant works were less popular. Works that appealed to sensory stimuli were welcomed (Li Xijian. 1998) as society at the time valued material and sensual pleasures and disparaged the spiritual, the cultural, and the intellectual. So the vulgar tastes and emphasis on desire filled literature (Zhu, Donglin; Zhu Xiaojin \& Long Quanming. 2010). Even some famous and aesthetically elegant works promoted the 'sex' in their narratives to increase sales ( $\mathrm{Li}$ Xijian. 1998). Letter from an Unknown Woman was no exception.

In order to improve sales, the publishers tried to emphasise the 'sex' and 'desire' in the novella. The woman's temerarious pursuit of her desired lover and her fantasies about their relationship implied were strong romantic themes that could be marketed as sexual in nature. Accordingly, the publishers highlighted those contents in the novella. In this novella, the woman's frantic love and fantasy about her love toward the writer were described as follows: 'I kissed the door-handle you had touched; I picked up a cigarette end you had thrown away, and it was sacred to me because your lips had pressed it...It was my mind to throw myself at your feet, and to beg you to keep me as a maid, as a slave.'(Zweig 1932, P33)...All those became the contents that the publishers highlighted in the introduction to this novella.

As publishers promoted selling Letter from an Unknown Woman in this way, the interpretation of the novella changed unwittingly. For the readers who were not familiar with Zweig's works, this novella was vulgar and provided erotic description that catered to mass interests. Although the novella's contents were distorted, the novella received more attention during this period because of its higher sales. However, one side effect was that this novella was regarded as kitsch.

After 2000, Jinglei Xu's adaption of this novella eliminated the side effect, and Letter from an Unknown Woman was better known in China. However, the social circumstances should be analysed before we discuss the spread of Letter from an Unknown Woman during this period.

One obvious social background since 2000 was the expansion of China's netizen population. According to the China Internet Network Information Center, the netizen population amounted to 6.49 hundred million by 2014. After China's Internet recovered from the Internet bubble, the the population of netizens quickly grew (Office of the Central Leading Group for Cyberspace Affairs, 
2015). With the Internet, Chinese netizens could access new multimedia entertainment, an important one being film. Although thousands of films are adapted from literary works, film still threatens the existence of literature because film provides the audience with a more vivid and encompassing experience than literature. Rampant Internet film piracy in China (Ye Jianhua \& Qiu, Zhiwei. 2016) made films easily and cheaply available to Chinese netizens; this added to the threat film posed to literature in China.

In this atmosphere, Letter from an Unknown Woman was adapted successfully to film by Jinglei Xu. In this film, the story was set in Beijing of the Republic of China. Xu used Chinese traditional music Pipa Yu (Whisper from Pipa) for the soundtrack, which improved significantly the sinicization of the film. The film lacked the eroticism that prior marketing of the novella promised. On the contrary, Letter from an Unknown Woman was presented as a sentimental love story. The novella 'caters to the cultural nostalgia toward the Republic China and accentuates wenyi sentiments by Europeanising the male figure.' (Guo, 2017). Here 'wenyi' (letters and arts) is a word about the particular way of life, distinctive cultural tastes, or a utilitarian vision of literature and arts (Guo, 2017). In contrast to the advertisement of the publishers in 1990s, the self-indulgent expression of sentiment was most obvious in this film. The differences between the effects of this film and the publishers' advertisement in 1990s relate to the policies of People's Republic of China.

The policies on the film have the following social backgrounds. The first social background was that China government recognised the 'culture', such as film, literature, music or historic site, as an industry which could generate profit and enhance China's soft power. Therefore, China culture industry constituted an integral component of the state's strategic plan (Xinhua News Agency, 2002). The second social background was the strict film censorship and distribution channel in China. Unlike book sales in 1990s, which had many channels apart from Xinhua bookstore in China, film distribution in China was censored by many institutional organisations, including the Film Censorship Board, the Film Re-censorship Board, the Film Bureau, the State administration of press, publication, radio, film and television, and the Propaganda Department of the Central Committee of the CCP. In 2002, regulations on the administration of films were issued. In the seventh chapter of the regulations, punishments were made more intense. In other words, compared to book publishing in 1990s, the film-production and distribution were administrated and censored more strictly after 2000 . Therefore, it was impossible for film producers to highlight the erotic nature of the film. It was in this restrictive environment that Jinglei Xu's made his film based on Letter from an Unknown Woman.

From this history of translation, publishing, and filming of this novella, we see that the spread of this novella through China depends on the cultural, economic, political, technical, and international conditions. The introduction of this novella to China began in a literary environment where Chinese intellectuals eagerly learned from the Western world. However, during this period, few lay people knew about this novella due to the low literacy rate and unrest resulting from wars and disasters. In the following years, the Great Cultural Revolution impeded the novella's circulation because of government demands. Reform and the increased openness of China brought new opportunities for the novella to spread widely throughout China. The period between 1978 and end of 1989 witnessed the recovery of China from the Great Cultural Revolution. The recovery happened in two spheres: the cultural and the economic. The recovery in each sphere resulted in the different interpretations of this novella. The next period experienced technological change, economic globalisation, and the emphasis on the culture industry. In this period, The interpretation of this film was more about wenyi artistically as opposed to eroticism because of the strict censorship of the government. The interpretation of this film was influenced significantly by government policy during this period. Nevertheless, the government cultural policy functioned significantly in almost every period after 1949.

Ever since 1949, depending on current circumstances, the government issued different cultural policies, which influenced the writing and reading of literature. During the Great Cultural Revolution, The Notification of May $16^{\text {th }}$ issued in 1966 requested that people should uphold the banner of the Great Cultural Revolution to expose the reactionary stand of the so-called academic authority and criticise reactionary thought in the academic, pedagogical, journalistic and publishing spheres (Party History Research Center of the CPC Central Committee, 2011). On January $3^{\text {rd }}$, The Notification about Newspaper was issued; it suggested that newspapers at the province and city level could be closed in order to carry on the Revolution. Because of such policies, many foreign literary works were banned from publication. Letter from an Unknown Woman was also banned. After the end of the Great 
Cultural Revolution, from the 1978 until the 1990s, new cultural policies were issued. On October $30^{\text {th }}$, Chairman Deng Xaioping attended the Fourth Congress of China Literature and Art Workers. At this congress, Deng Xiaoping remarked that the literature and art was not necessary to function for the temporary, concrete, and directive political missions, and the leading of CCP should help for the literature and art workers to improve the levels and prosper the literature and art (Deng, Xiaoping. 1994). Deng Xiaoping's opinions helped to liberate literature from the restrictions of the Great Cultural Revolution. This changed caused Letter from an Unknown Woman to be re-translated and published. In the 1990s, the Chinese government developed the culture industry using industry policies. Through these policies, the government no longer managed the culture industry economically, and the direct or indirect public administration on such industry replaced the economic management (Yuan, He. 2017). On the one hand, the culture industry prospered, and on the other hand, some side effects appeared such as the enthusiastic pursuit of profit. The interpretation changed during this period. After 2000, the strategic importance of the culture industry was recognised. In 2003, the Third Session of the Sixteenth Central Committee of CCP passed The Decisions on the Issues about Improving the Socialist Market Economic System, which promoted the strategic position of culture industry. Accordingly, the culture industry prospered further. In this condition, Letter from an Unknown Woman was adapted into film and became well known by a large proportion of people in China. Although the culture industry exerted a direct effect on literature consumption and production, other factors were more critical in deciding the cultural policies.

Behind the cultural policies mentioned above, we find the complicated social backgrounds, such as economic changes, political movements, cultural ideologies, and technological innovations. Those factors prompted the government to adopt different policies to respond to these different situations. The spread and interpretation of the novella Letter from an Unknown Woman reflected the different policies and the corresponding complicated social backgrounds. In brief, the complicated social background factors affected the cultural policies issued by the government, and the cultural policies influenced the spread of foreign literary works in China. This is a model of the relationship between literary works and the social background ever since 1949. This model also fits on the relationship between literary works and the social background before 1949 .

Ever since the end of Qing dynasty, the government of China began to issue a series of policies to encourage the translation of foreign works. The policies resulted in the establishment of numerous private journals and newspapers, and the prosperity of the translations by both the government and folk organisations. The intellectuals in that period endeavoured to translate foreign works into Chinese. With this social trend, Letter from an Unknown Woman was translated into Chinese. In this process, we find that social background factors decided government policies and, in turn, the policies influenced the fate of this novella in China.

In conclusion, the translation and interpretation of Letter from an Unknown Woman was determined by complicated social circumstances. Political power was the primary factor influencing the novella's situation in China, but other social factors played a part as well. What this indicates is the theme and meaning of this novella are not fixed; they reflect current circumstances. In other words, Letter from an Unknown Woman is a mirror. Look at it, and we'll see where we are now.

\section{REFERENCES}

[1] Chen, zhongyi. Focusing on China Avant-garde Poem. Beijing: China Social Sciences Publishing House. 2009.

[2] Stefan Zweig. Letter From an Unknown Woman. New York: The Viking Press. 1932

[3] Deng, Xiaoping.The Speech in Fourth Congress of China Literature and Art Workers. In Selected Works of Deng Xiaoping. Beijing: People's Publishing House. 1994.

[4] Di, Aiying. Indirect Translation in China:from 1919 to 1949). Journal of UEST of China (Social Science Edition), 9(4), 59-62. 2007.

[5] Guo, Moruo;Liu, Yuanshu. Autobiography of Guo Moruo.Anhui Literature and Art Publishing House. 1997.

[6] Hu, Shi. Notion of Literary Evolution and Improvement of Drama. New Youth, 5(4), 10. 1918.

[7] Li, Xijian. Reshaping Humanity: The Evolution of Humanity in Populace's Aesthetic. Hubei People's Publishing House. 1998.

[8] Lyu, Yonglin. The 1990s' Eroticism: Concurrently Discussing the Historical Metaphysical Function of Wei Hui's Novels. Academic Journal of Jinyang, (5), 35-41. 2015. 
[9] Ma, Shikui.The Translation of Foreign Literature in Great Cultural Revolution. Chinese Translators Journal, (3), 65-69. 2003.

[10] Mao, Dun. European War and Literature. The Fiction Monthly. 15.8(1924): 5-23

[11] Wang, Fuhe. The Ratio Imbalance of Foreign Literature Translation and Publication). China Book Review, (7), 10-12. 1996.

[12] Wei, Maoping. The Investigation on the Translation of German Literature in Late Qing Dynasty and Republic of China Periods. Shanghai Foreign Language Education Press. 2004.

[13] Xu, Fei. Discussion on Happy Ending Literature. Novel Review, (2), 62-66. 1989.

[14] Yang, Rengen. Romain Rolland in translation. The Commercial Press. 1928.

[15] Ye, Jianhua; Qiu, Zhiwei. Multidimensional Analysis of Internet Film Piracy in China. Journal of Shenzhen University(Humanities \& Social sciences), 33(3), 95-99. 2016.

[16] Yuan, He. The Study on the Culture Construction of Nanjing Kuomintang Government(1927-1949). Chinese National Academy of Arts. 2017.

[17] Zhang, Guojun. Power Discourse and the Translation of Foreign Literature during the Period of Cultural Revolution. South China Agricultural University(Humanities \& Social sciences), 7(4), 99-103. 2008.

[18] Zhang, Yan; Liu, Yifan. Everlasting Charm of Zweig. Guangming Daily. (2015 9 8).

[19] Liu, Yushu. Heinrich, Schiller and Zweig: Collection of German-speaking Nation Literature. Beijing: Peking University Press. 1987.

[20] Party History Research Center of the CPC Central Committee. Chronicle of CCP Events. Beijing: CCP History Press, 2011.

[21] Zhu, Donglin; Zhu, Xiaojin; Long, Quanming. History of Contemporary China Literature: 1917-2000. Second Volume. Beijing: Peking University Press. 2010.

[22] Zhu, Shenglong. Buying and Selling Book Numbers: the Centenary Race for the Publication Profit. Publishing Economy, (6), 35-38. 2001.

[23] Agency, X. N. Full Text of Jiang Zemin's Report at the 16th Party Congress. Retrieved May 20, 2007, from http://china.org.cn/english/2002/Nov/49107.htm\#6. 2002.

[24] Guo, S. Wenyi, Wenqing and pure love: The European imaginary in Xu Jinglei's films. Journal of Chinese Cinemas, 8061(August), 1-18. https://doi.org/10.1080/17508061.2017.1368237.2017.

[25] Office of the Central Leading Group for Cyberspace Affairs. 20-years Internet History in China. Retrieved from http://www.cac.gov.cn/2015-02/03/c_1114227306.htm

Citation: Ruihui Han. "Social Background and the Spread of Letter from an Unknown Woman in China". International Journal of Humanities Social Sciences and Education (IJHSSE), vol 5, no.12, 2018, pp. 121-127. doi:http://dx.doi.org/10.20431/2349-0381.0512012.

Copyright: (c) 2018 Authors. This is an open-access article distributed under the terms of the Creative Commons Attribution License, which permits unrestricted use, distribution, and reproduction in any medium, provided the original author and source are credited. 